\title{
Design, Synthesis, and In Vitro Evaluation of Novel Indolyl DiHydropyrazole Derivatives as Potential Anticancer Agents
}

\author{
Katharigatta N. Venugopala ${ }^{1,2, * \mathbb{D}}$, Mohammed Habeebuddin ${ }^{3}$, Bandar E. Aldhubiab ${ }^{1}$ and Afzal Haq Asif ${ }^{4, *}$ \\ 1 Department of Pharmaceutical Sciences, College of Clinical Pharmacy, King Faisal University, \\ Al-Ahsa 31982, Saudi Arabia; baldhubiab@kfu.edu.sa \\ 2 Department of Biotechnology and Food Technology, Durban University of Technology, \\ Durban 4001, South Africa \\ 3 Department of Biomedical Sciences, College of Medicine, King Faisal University, Al-Ahsa 31982, Saudi \\ Arabia; Hmohammed@kfu.edu.sa \\ 4 Department of Pharmacy Practice, College of Clinical Pharmacy, King Faisal University, \\ Al-Ahsa 31982, Saudi Arabia \\ * Correspondence: kvenugopala@kfu.edu.sa (K.N.V.); ahasif@kfu.edu.sa (A.H.A.)
}

check for updates

Citation: Venugopala, K.N.; Habeebuddin, M.; Aldhubiab, B.E.; Asif, A.H. Design, Synthesis, and In Vitro Evaluation of Novel Indolyl DiHydropyrazole Derivatives as Potential Anticancer Agents. Molecules 2021, 26, 5235. https:// doi.org/10.3390/molecules26175235

Academic Editors: David StC Black and Naresh Kumar

Received: 25 May 2021

Accepted: 12 August 2021

Published: 29 August 2021

Publisher's Note: MDPI stays neutral with regard to jurisdictional claims in published maps and institutional affiliations.

Copyright: (c) 2021 by the authors. Licensee MDPI, Basel, Switzerland. This article is an open access article distributed under the terms and conditions of the Creative Commons Attribution (CC BY) license (https:/ / creativecommons.org/licenses/by/ $4.0 /)$.

\begin{abstract}
Indoles derived from both natural sources or artificial synthetic methods have been known to interact with aryl hydrocarbon receptors $(\mathrm{AhR})$, and exhibit anticancer activity. In light of these attractive properties, a series of hybrid molecules with structural features of indoles, i.e., those bearing a pyrazoline nucleus, were evaluated for their enhanced anticancer activity. The designed molecules were subjected to molecular docking in order to screen for potential AhR interacting compounds, and the identified indolyl dihydropyrazole derivatives were synthesized. The synthesized compounds were characterized, and their cytotoxicity was evaluated against four human cancer cell lines using the MTT assay. Based on the Glide g-score, H-bonding interactions and bonding energy of 20 candidate molecules were selected for further analysis from the 64 initially designed molecules. These candidate molecules have shown promising anti-proliferative activity against the cell lines tested. Among these candidate molecules, the compounds with hydroxy phenyl substitution on the pyrazoline ring have shown potent activity across all the tested cell lines. The designed scaffold was proven effective for screening potential candidate molecules with anticancer properties, and may be further optimized structurally for yielding the ideal anti-tumorigenic compound for the treatment of various cancers.
\end{abstract}

Keywords: AhR inhibitors; indoles; pyrazolines; anti-proliferative; molecular docking

\section{Introduction}

The aryl hydrocarbon receptor $(\mathrm{AhR})$ is a cytosolic regulatory protein of the PerARNT-Sim (PAS) protein family, and can be stimulated by several endogenous and exogenous ligands. The $\mathrm{AhR}$, in the absence of a ligand, is present in the cytoplasm as a tetrameric chaperone complex, which includes the dimer of Hsp90, p23, immunophilin-like X-associated protein 2 (XAP2), and AhR-interacting protein (AIP) [1-3]. Ligands binding to the complex induces structural changes, which in turn results in the dissociation of the chaperone complex, exposing the nuclear localization sequence which enables its translocation towards the nucleus along with the ligand [4,5]. The AhR nuclear transporter (ARNT) association promotes the formation of the high-affinity DNA-binding complex, a complex of heterodimeric transcription factor [6]. The formation of the AhR/ARNT heterodimer enables it to bind to the DNA replication-related element (DRE) of the DNA sequence, which in turn leads to the remodeling of the chromatin network triggering transcription of downstream genes [7-9]. The AhR has been reported to regulate various biological pathways, and play a major role in the maintenance of normal cellular functions, which includes maintaining intestinal homeostasis, epithelial barrier function, host immune function \& regulation, epidermal formation, organogenesis, cell migration, cell cycle, and proliferation [10-14]. 
Aberrant AhR expression often leads to functional anomalies, and is the underlying reason for cancer, as evident from the various in vitro and in vivo models of cancer, with noticeable divergences in pro- and anti-tumorigenic profiles. Moreover, different classes of ligands modulate the AhR functionality, and ligands of the same class in fact have been reported to produce different tumorigenic outcomes by influencing the AhR functionality. However, AhR is considered as a potentially critical drug target, which has the potential to be modulated by several classes of ligands [15].

The activation of $\mathrm{AhR}$ regulates target genes controlling inflammation, which includes IL-6, IL-22, PTGS2, VEGFA, and CYP1A1, and acts as an important regulator of immunity and inflammation $[16,17]$. Hence, modifications in the AhR expression or its activation may lead to significant adverse health outcomes. The activation of AhR by indoxyl sulfate (IS) has been described to modulate IL-6 and various CYP enzymes (CYP1A1, CYP1A2, CYP1B1) which play an important role in regulating the inflammation in proximal tubular cells [18-20]. The agonists of AhR can modulate the differentiation of certain T cells and recent studies have reported indole-3-pyruvic acid (IPA) to promote the differentiation of Tr1 cells, resulting in an increase in IL-10 production which in turn modulates the inflammatory and immune homeostasis in the intestine [21,22].

6-Formylindolo (3,2-b) carbazole (FICZ), a photoproduct of tryptophan, can induce AhR activation which mediates the inhibition of inflammation by antagonizing the effect of IL-6 in lipopolysaccharide-treated dendritic cells and dextran sulphate sodium-induced colitis [23-25]. FICZ was reported to establish FICZ/AHR/CYP1A1-dependent negative feedback mechanism to regulate active cellular processes [26]. Another metabolite of tryptophan, 3,3'-diindolylmethane (DIM), which is a selective AhR modulator, has been reported to inhibit AhR/ARNT-dependent apoptosis and autophagy, and plays an active role in protecting the hippocampal cells against hypoxia [27]. The activation of AhR by indole-3-carbinol (I3C) initiates the chain reactions involving Rbx1 E3 ubiquitin ligase which promotes the ubiquitination of $\mathrm{ER} \alpha$ and eventually leads to the loss of $\mathrm{ER} \alpha$-mediated proliferation [28].

Indole derivatives were reported to interact with various intracellular targets, including AhR and cyclin-dependent kinases (CDKs), and were found to exhibit anticancer activity. In particular, indolocarbazoles obtained from natural and synthetic origin have been shown to have anti-proliferative activities in different cell lines [29,30].

Based on previous studies involving indoles and pyrazolines, it may be hypothesized that a hybrid molecule having structural characteristics of both indoles and pyrazolines may present a substantial improvement in the anti-proliferative activity of the indole derivatives. In this purview, our group designed potential compounds with indole moiety attached at the third position of the pyrazoline ring with subsequent substitution of the pyrazoline nitrogen atom, resulting in the formation of a 5-(indol-3-yl)-pyrazoline-1-carboxamide derivative. The indole-pyrazoline hybrid compounds were designed and screened by in silico approaches, and the selected molecules were synthesized and evaluated for potential anti-proliferative activity.

\section{Materials and Methods}

\subsection{Molecular Modeling Studies}

\subsubsection{Ligand Preparation}

The designed molecule structures were drawn using ChemDraw 18.2 (ChemOffice 2018, Perkin-Elmer Informatics, Shelton, CT, USA), and the files were saved in a .sdf format. The Chem3D 18.2 software was used to minimize the energy of the chemical structure of each compound, such that the energy difference between the bonds was $0.001 \mathrm{~kJ} / \mathrm{mol}$, and a single minimum energy 3D conformation of the compound was subsequently generated. These 3D structure files were opened using Maestro 11.2 (Schrodinger, LLC, New York, USA), and ligand preparation was performed using the LigPrep tool [31], with a filtration criteria of molecular weight of $\leq 150$ and $\geq 500$, and force field OPLS3. The default settings were maintained with the following options: ionization; generate possible states at target 
pH 7.0 \pm 2.0; Epik program for ionization states; desalt; generate tautomers; stereoisomers: retain specified chiralities; stereoisomers; generate at most 32 per ligand; output format: maestro. The LigPrep results were verified, and one conformation per ligand was selected based on their Epik state penalty (in $\mathrm{kcal} / \mathrm{mol}$ ) [32].

\subsubsection{Protein Preparation}

The crystal structure of the PAS-A domain of AhR (PDB ID: 4M4X) [33] was imported into a Maestro protein preparation tool from RCSB PDB, and the protein structure was modified under more stringent criteria in terms of integrity, and missing residues were included using the prime program. Later hydrogen atoms were added to the protein and optimization and minimization of the energy of the protein was evaluated. The $\mathrm{H}-$ bond assignment section of the software was used for optimizing the hydrogen bonding network, a process in which the samples' orientation can be altered and Asn, Gln, and/or His side chains can be flipped at a specified $\mathrm{pH}$ value. The protein protonation states were maintained under the $\mathrm{pH}$ range of $7.0 \pm 2.0$, and the geometry of the chemical structure was optimized with a RMSD maxima of $0.3 \AA$ using the OPLS3 force field $[34,35]$.

\subsubsection{Active Site Prediction}

The protein was studied and possible binding sites were characterized using the SiteMap tool [36]. SiteMap analysis highlights the regions surrounding the binding sites, which are potentially convenient for docking the hydrophobic functional units or ligand H-bond acceptors, donors, or metal-chelating functional groups. Out of the five binding sites predicted by the Sitemap, one binding site was chosen for further docking investigations $[37,38]$.

\subsubsection{Receptor Grid Generation}

Around the chosen binding site of the protein $4 \mathrm{M} 4 \mathrm{X}$, a grid was generated by using the Glide program by selecting one residue in the binding cavity with a grid box of $16 \times 16 \times 16 \AA$, and a length of $8 \AA$ corresponding to the $\mathrm{x}, \mathrm{y}$, and $\mathrm{z}$ coordinates of 11.55 , -8.28 , and 8.78 , respectively. With these coordinates and default parameters, the grid file was generated and saved for further docking studies [39].

\subsubsection{Molecular Docking Study}

In the Glide program, flexible docking was employed to identify the possible binding interactions, and affinity between the designed molecules and the predicted binding site of protein $4 \mathrm{M} 4 \mathrm{X}$. The generated receptor grid files were opened using the Glide program, and the prepared ligands from the workspace were included to study the binding interaction with the protein $4 \mathrm{M} 4 \mathrm{X}$ using the standard precision (SP) docking program with all default parameters unaltered $[34,35,40,41]$.

\subsection{Synthesis of Pyrazoline Derivatives of Indole}

All the chemicals were purchased from Sigma-Aldrich, and all the solvents for the use were of laboratory grade. The materials for in vitro evaluation were obtained from Sigma-Aldrich Ltd. The reactions were monitored by thin layer chromatography (TLC) on precoated silica gel 60 F254 (Merck, Darmstadt, Germany), and spots were visualized with UV light. Merck silica gel (80-120 mesh; Merck, Darmstadt, Germany) was used for column chromatography. All the synthesized compounds were purified by recrystallization and column chromatography. Melting points were determined via an open capillary method and were uncorrected. IR spectra were recorded on a Perkin-Elmer FT-IR 240-C Spectrophotometer using KBr optics (Perkin-Elmer, Waltham, MA, USA). Next, 1H-NMR spectra were recorded on Gemini Varian (Varian, Palo Alto, CA, USA) 200 MHz, Bruker (Bruker Bioscience, Billerica, MA, USA) AV $300 \mathrm{MHz}$, and Unity (Varian) $400 \mathrm{MHz}$ spectrometer in DMSO-d6 or CDCl3 using TMS as an internal standard. Electron impact (EI) and chem- 
ical ionization mass spectra were recorded on a VG $7070 \mathrm{H}$ instrument (Micromass, St Leonards-0n Sea, UK) at $70 \mathrm{eV}$.

\subsubsection{One-Pot Synthesis of Pyrazolines (3a-k)}

To a mixture of indole-3-aldehyde $(1 \mathrm{mM})$ and substituted acetophenone $(1 \mathrm{mM})$, sodium hydroxide $(4 \%, 3 \mathrm{mM})$ and hydrazine $(1.5 \mathrm{mM})$ were added in $25 \mathrm{~mL}$ of ethyl alcohol $(96 \% v / v)$, and the resultant mixture of reaction was subjected to heating under reflux with constant stirring for about 6-8 h (Figure 1). The reaction completion was monitored by TLC and the color change was assessed. After confirmation of completion of the reaction, the reaction mixture was allowed to cool to room temperature and kept in the freezer section of the refrigerator overnight $\left(<0^{\circ} \mathrm{C}\right)$. The resultant solid produced was filtered under vacuum, and washed with cold water several times, oven dried, and recrystallized using methanol as the solvent to obtain the pyrazolines (3a-t) $[42,43]$.

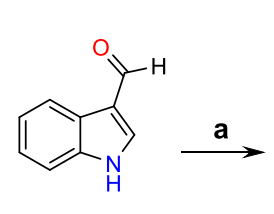

1

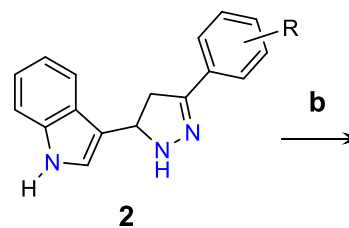

2<smiles>[R]c1ccc(C2=NN(C(=O)c3ccccc3)C(c3c[nH]c4ccccc34)C2)cc1</smiles>

3a-k

c

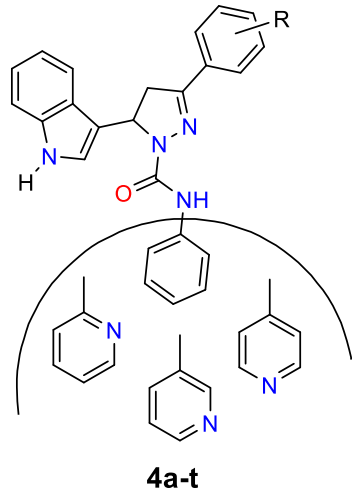

Figure 1. Scheme for the synthesis of indolyl pyrazolines. a. $\mathrm{NaOH}, \mathrm{NH}_{2} \mathrm{NH}_{2}, 6-8 \mathrm{~h}$, reflux, b. THF, $(\mathrm{Et})_{3} \mathrm{~N}$, phenyl chloroformate, $2 \mathrm{~h}$, below $5^{\circ} \mathrm{C}, \mathrm{c}$. Ar- $\mathrm{NH}_{2}, \mathrm{RT}$, stirring, 3-4 h.

2.2.2. Procedure for the Synthesis of 5-(1H-Indol-3-yl)-3-substituted-N-(pyridin-2-yl)-4,5dihydro-1H-pyrazole-1-carboxamide $(4 a-t)$

Appropriate amounts of pyrazoline derivatives $(1 \mathrm{mM})$ dissolved in dry tetrahydrofuran were added to a mixture of phenyl chloroformate $(1 \mathrm{mM})$ and triethylamine $(1 \mathrm{mM})$ in dry tetrahydrofuran, and an ice-cool condition was maintained. The resultant reaction mixture was stirred continuously for $2 \mathrm{~h}$ at temperatures below $5{ }^{\circ} \mathrm{C}$ (Figure 1). The resultant solid was removed by filtration and aryl/heteroaryl amine was added to the filtrate, followed by stirring for about $3-4 \mathrm{~h}$ at room temperature. The obtained solid was separated, dried, and recrystallized in suitable solvent.

\subsection{Anti-Proliferative Activity}

\subsubsection{Cell Culture}

Human tumor cell lines (provide by National Centre for Cell Science (NCCS)), Pune, India.), i.e., A-549 (non-small cell lung cancer), MCF-7 (mammary gland adenocarcinoma), Hep G-2 (liver cancer), and DU-145 (prostate cancer) cells, were grown in RPMI 1640 medium or DMEM medium enriched with Glutamax-I and glucose. Both the cell cul- 
ture medias were supplemented with $10 \%(v / v)$ fetal calf serum, antibiotics penicillin $(100 \mathrm{IU} / \mathrm{mL})$, and streptomycin $(100 \mu \mathrm{g} / \mathrm{mL})$, and maintained at $37^{\circ} \mathrm{C}$. The cell viability test was performed before each assay using the trypan blue exclusion method and assays were performed with cells showing $<95 \%$ viability.

\subsubsection{Cytotoxicity Assay}

The $\mathrm{IC}_{50}$ values of the compounds were calculated by a non-linear regression model with the help of normalized dose-response data acquired by the MTT assay [44,45]. The cytotoxic activity of tested compounds was evaluated using the cell-based spectrophotometric assay with an MTT reagent. Briefly, $5 \times 10^{3}$ cells were transferred to each well of a 96-well plate (Sigma-Aldrich, Mumbai, India) and $100 \mu \mathrm{L}$ of the culture medium was added with the tested compounds at the concentrations of 1-100 $\mu \mathrm{mol} / \mathrm{L}$. The cells were incubated for $72 \mathrm{~h}$, and then $10 \mu \mathrm{L}$ of MTT $(5 \mathrm{mg} / \mathrm{mL})$ (Sigma-Aldrich, Mumbai, India) was added to each well. The plates were incubated for $4 \mathrm{~h}$ at $37^{\circ} \mathrm{C}$. During this period, insoluble formazan was produced, which was then dissolved by the addition of $100 \mu \mathrm{L}$ of $10 \%$ sodium dodecyl sulfate into each well and kept aside for an additional $12 \mathrm{~h}$ for the dissolving the formazan. The absorbance of each plate was read at $540 \mathrm{~nm}$ and $630 \mathrm{~nm}$ reference wavelength using the Epoch Microplate Spectrophotometer (Biotek Instruments Inc., VT, Winooski, VT, USA). The blank absorbance was considered as the control, and the readings were expressed as percentage of the control.

\section{Results and Discussion}

\subsection{Molecular Modeling Studies}

AhR is being extensively studied due to its role as an intermediary of various carcinogens from environmental pollutants, and ideal AhR binding ligand 2,3,7,8-tetrachlorodibenzo-pdioxin (TCDD) was identified for its tumor eliciting properties in several models. However, the function of AhR and AhR ligands have not been widely explored in tumor cells. In this study, we selected the AhR PAS-A domain, with the resolution of a $2.55 \AA$ crystal structure of the protein (PDB ID: 4M4X) for preliminary docking analysis. Based on the structural analysis of the indole compounds having a binding affinity towards $\mathrm{AhR}$, around 64 novel molecules were designed as having a basic structure of 5-(indol-3-yl)-4,5-dihydro1H-pyrazole-1-carboxamide with different aryl substitutions on the pyrazoline ring, and an aryl/heteroaryl amino group for amide formation (Supplementary Data). The structures were drawn and minimized in 3D, and later subjected to LigPrep for obtaining potential ligand designs for molecular docking. During ligand preparation, structures were excluded based on their molecular weight $(>500 \mathrm{Da})$. The chosen structures were forwarded for docking calculations. All the structures designed were well under 500 Daltons, so all of them were considered for the molecular docking study.

The crystal structure of the PAS-A domain of AhR with PDB ID: 4M4X was retrieved from the RCSB-PDB. The structure of the protein comprises of PER-ARNT-SIM (PAS) domains of the AhR-ARNT complex. The protein data were entered into protein preparation wizard for refinement. The H-bond assignment section was used for optimizing the hydrogen bonding network, a process by which the sample's water affinity may be changed by flipping Asn, Gln, and/or His side chains at a specified $\mathrm{pH}$ value. The $\mathrm{pH}$ adjustment changed the protonation states of residues and ligands accordingly, and is useful for determining the experimental conditions. The restrained minimization section was used to fix the clashes that may occur with adding hydrogens or filling missing sidechains. By default, an RMSD of $0.3 \AA$ was used, which minimized both the hydrogens and heavy atoms using harmonic penalty constraints. As there was no active co-crystallized ligand, the SiteMap tool of the Maestro was employed for detecting the potential binding sites based on the protein parameters. It yielded five binding sites, in which the top scored binding site was that of the AhR-ARNT protein-protein interaction domain with a score and volume of 1.253 and 193.109, respectively, which were subsequently omitted. Later, the binding site 
was chosen based on the score and volume, as well as the hydrophobic and hydrophilic contributions and information of binding residues based on pre-existing literature.

The receptor grid file was generated by choosing a random point in the binding site of choice by enclosing the grid box size in the workspace constrained to $8 \AA$. The molecules selected from LigPrep were subjected to flexible docking using the SP docking program set with default parameters. The docking score, the number of hydrogen bonds, amino acid residues, and the Glide score of the selected molecules along with the protein are summarized in Tables 1 and 2. The compounds were found to possess a significant binding affinity with the binding site of the protein by interactions with the residues: Phe 115, Leu 116, Gln 118, Asn 121, Glu 211, Asn 232, Gln 234, Gln 235, Arg 236, Ile 262, and Thr 264, respectively. The 5-(indol-3-yl)-pyrazolines (4a-t) Glide G-score was in the range of -6.255 to -4.81 , and the Glide energy range was from -43.506 to -36.142 . The highest glide G-score was found to be -6.255 , which corresponded to the compound 4h [3-(3-Hydroxyphenyl)-5-(1H-indol-3-yl)-N-(pyridin-2-yl)-4,5-dihydro-1H-pyrazole-1carbox-amide], and was found to form three hydrogen bond interactions with the protein residues Leu $116(1.95 \AA, 1.72 \AA)$ and Gln $118(2.02 \AA)$. The 2D and 3D representation of the binding pattern of the compounds are illustrated in Figures 2-6. The H-bonding interactions formed by the ligands and protein residues are $\mathrm{N}-\mathrm{H} \cdots \mathrm{O}, \mathrm{O}-\mathrm{H} \cdots \mathrm{N}$ and/or $\mathrm{O}-\mathrm{H} \cdots \mathrm{O}$. Apart from the $\mathrm{H}$-bonding, other weaker interactions with the active site residues include electrostatic and hydrophobic bonds. Most of the compounds interacted via non- $\mathrm{H}-$ bonding to the Gln 171, Arg 212, Cys 213, Phe 214, Phe 233 residues with $\pi-\pi$ stacking. The $\mathrm{H}$-bond interactions of promising compounds along with the standard are presented in Table 2 . The $\mathrm{H}$-bond length and bonding interaction in compounds 4a-t are comparatively significant with respect to the standard. The basic nucleus of 5-(indol-3-yl)-4,5-dihydro- $1 \mathrm{H}-$ pyrazole-1-carboxamide played an important role in the binding interactions as it possesses both the H-bond accepting and donating groups in the binding region of the protein, which allows the ligand to bind with high affinity and exhibit optimum binding conformation with high docking and the Glide G-score. In addition, the side chain of 2-amino pyridine and hydroxy substitution on the aryl ring in all the positions also contributed to a good binding score in case of all the molecules designed in this study. Based on the docking score and H-bonding interactions in the complex, the top 20 molecules were selected for synthesis and in vitro anti-proliferative activity evaluation.

Table 1. Docking results of the selected compounds.

\begin{tabular}{cccccc}
\hline Compound & $\mathbf{R}$ & R1 & $\begin{array}{c}\text { Glide } \\
\text { g-Score }\end{array}$ & $\begin{array}{c}\text { Glide } \\
\text { h-Bond }\end{array}$ & $\begin{array}{c}\text { Glide } \\
\text { Energy }\end{array}$ \\
\hline $4 \mathrm{a}$ & $\mathrm{H}$ & Pyridin-2-yl & -4.825 & -0.25 & -36.657 \\
$4 \mathrm{~b}$ & $2-\mathrm{Cl}$ & Pyridin-2-yl & -4.901 & -0.219 & -37.331 \\
$4 \mathrm{c}$ & $3-\mathrm{Cl}$ & Pyridin-2-yl & -5.84 & -0.268 & -38.583 \\
$4 \mathrm{~d}$ & $3-\mathrm{CH}$ & Pyridin-2-yl & -5.071 & -0.221 & -37.89 \\
$4 \mathrm{e}$ & $3-\mathrm{OCH}$ & Pyridin-2-yl & -4.892 & -0.17 & -38.54 \\
$4 \mathrm{f}$ & $4-\mathrm{OCH}$ & Pyridin-2-yl & -4.982 & -0.216 & -38.981 \\
$4 \mathrm{~g}$ & $2-\mathrm{OH}$ & Pyridin-2-yl & -5.835 & -0.529 & -39.868 \\
$4 \mathrm{~h}$ & $3-\mathrm{OH}$ & Pyridin-2-yl & -6.255 & -0.562 & -38.825 \\
$4 \mathrm{i}$ & $4-\mathrm{OH}$ & Pyridin-2-yl & -4.81 & -0.161 & -36.75 \\
$4 \mathrm{j}$ & $2-\mathrm{NO} 2$ & Pyridin-2-yl & -4.876 & -0.237 & -38.004 \\
$4 \mathrm{k}$ & $3-\mathrm{NO} 2$ & Pyridin-2-yl & -4.939 & -0.314 & -39.227 \\
$4 \mathrm{l}$ & $2-\mathrm{Cl}$ & Pyridin-3-yl & -4.932 & -0.157 & -41.181 \\
$4 \mathrm{~m}$ & $2-\mathrm{OH}$ & Pyridin-3-yl & -5.137 & -0.329 & -37.86 \\
$4 \mathrm{n}$ & $3-\mathrm{OH}$ & Pyridin-3-yl & -6.069 & -0.449 & -38.018 \\
$4 \mathrm{o}$ & $4-\mathrm{Cl}$ & Pyridin-4-yl & -4.882 & -0.569 & -41.003 \\
$4 \mathrm{p}$ & $4-\mathrm{OCH}$ & Pyridin-4-yl & -4.816 & -0.282 & -36.142 \\
$4 \mathrm{q}$ & $2-\mathrm{OH}$ & Pyridin-4-yl & -5.022 & -0.556 & -41.616 \\
$4 \mathrm{r}$ & $3-\mathrm{OH}$ & Pyridin-4-yl & -6.152 & -0.458 & -38.088 \\
$4 \mathrm{~s}$ & $2-\mathrm{OH}$ & Phenyl & -5.299 & -0.32 & -38.74 \\
$4 \mathrm{t}$ & $4-\mathrm{OH}$ & Phenyl & -6.17 & -0.32 & -43.506 \\
\hline
\end{tabular}


Table 2. H-bonding interactions of compounds 4(a-t) with the protein residues.

\begin{tabular}{|c|c|c|c|c|}
\hline Compound & $\mathbf{R}$ & R1 & $\begin{array}{c}\text { Amino Acid } \\
\text { Residues } \\
\text { (H-Bond Length } \AA \text { ) }\end{array}$ & $\begin{array}{c}\text { No. of } \\
\text { H-Bonding } \\
\text { Interactions }\end{array}$ \\
\hline $4 a$ & $\mathrm{H}$ & Pyridin-2-yl & Ile $262(2.54)$ & 1 \\
\hline $4 \mathrm{~b}$ & $2-\mathrm{Cl}$ & Pyridin-2-yl & Phe 115 (1.47) & 1 \\
\hline $4 \mathrm{c}$ & $3-\mathrm{Cl}$ & Pyridin-2-yl & $\begin{array}{c}\text { Arg } 236 \text { (1.94), Phe } \\
115 \text { (1.06) }\end{array}$ & 2 \\
\hline $4 d$ & $3-\mathrm{CH} 3$ & Pyridin-2-yl & Ile $262(2.05)$ & 1 \\
\hline $4 e$ & 3-OCH3 & Pyridin-2-yl & $\begin{array}{c}\text { Ile } 262 \text { (2.85), Phe } 115 \\
\text { (3.02) }\end{array}$ & 2 \\
\hline $4 f$ & 4-OCH3 & Pyridin-2-yl & Asn 121 (2.42) & 1 \\
\hline $4 g$ & $2-\mathrm{OH}$ & Pyridin-2-yl & $\begin{array}{c}\text { Ile } 262(1.65,2.76), \text { Gln } \\
234(2.12)\end{array}$ & 3 \\
\hline $4 \mathrm{~h}$ & $3-\mathrm{OH}$ & Pyridin-2-yl & $\begin{array}{c}\text { Leu } 116(1.95,1.72) \\
\text { Gln } 118(2.02)\end{array}$ & 3 \\
\hline $4 \mathrm{i}$ & $4-\mathrm{OH}$ & Pyridin-2-yl & Gln 235 (3.00) & 1 \\
\hline $4 \mathrm{j}$ & 2-NO2 & Pyridin-2-yl & Arg 236 (2.99) & 1 \\
\hline $4 \mathrm{k}$ & 3-NO2 & Pyridin-2-yl & Arg 236 (3.13) & 1 \\
\hline 41 & $2-\mathrm{Cl}$ & Pyridin-3-yl & Leu $116(2.20)$ & 1 \\
\hline $4 \mathrm{~m}$ & $2-\mathrm{OH}$ & Pyridin-3-yl & $\begin{array}{c}\text { Gln } 118(2.65) \\
\text { Asn } 232 \text { (3.25), Glu }\end{array}$ & 1 \\
\hline $4 n$ & $3-\mathrm{OH}$ & Pyridin-3-yl & $\begin{array}{c}211(3.09), \\
\text { Arg } 236(2.04), \text { Ile } 262 \\
(2.01)\end{array}$ & 4 \\
\hline 40 & $4-\mathrm{Cl}$ & Pyridin-4-yl & $\begin{array}{c}\text { Gln } 234 \text { (2.01), Ile } 262 \\
\text { (3.33) }\end{array}$ & 4 \\
\hline $4 \mathrm{p}$ & $4-\mathrm{OCH} 3$ & Pyridin-4-yl & $\begin{array}{c}\text { Ile } 262 \text { (2.85), Phe } 115 \\
\text { (3.02) }\end{array}$ & 2 \\
\hline $4 q$ & $2-\mathrm{OH}$ & Pyridin-4-yl & $\begin{array}{c}\text { Leu } 116(1.95,1.72), \text { Ile } \\
262(1.65,2.76)\end{array}$ & 4 \\
\hline $4 \mathrm{r}$ & $3-\mathrm{OH}$ & Pyridin-4-yl & $\begin{array}{c}\text { Glu } 211 \text { (2.98), Arg } 236 \\
\text { (2.62) }\end{array}$ & 2 \\
\hline $4 \mathrm{~s}$ & $2-\mathrm{OH}$ & Phenyl & $\begin{array}{c}\text { Gln } 234(3.44), \text { Gln } 118 \\
(3.08), \\
\text { Thr } 264(2.89)\end{array}$ & 3 \\
\hline $4 \mathrm{t}$ & $4-\mathrm{OH}$ & Phenyl & Gly 235 (2.93) & 1 \\
\hline
\end{tabular}

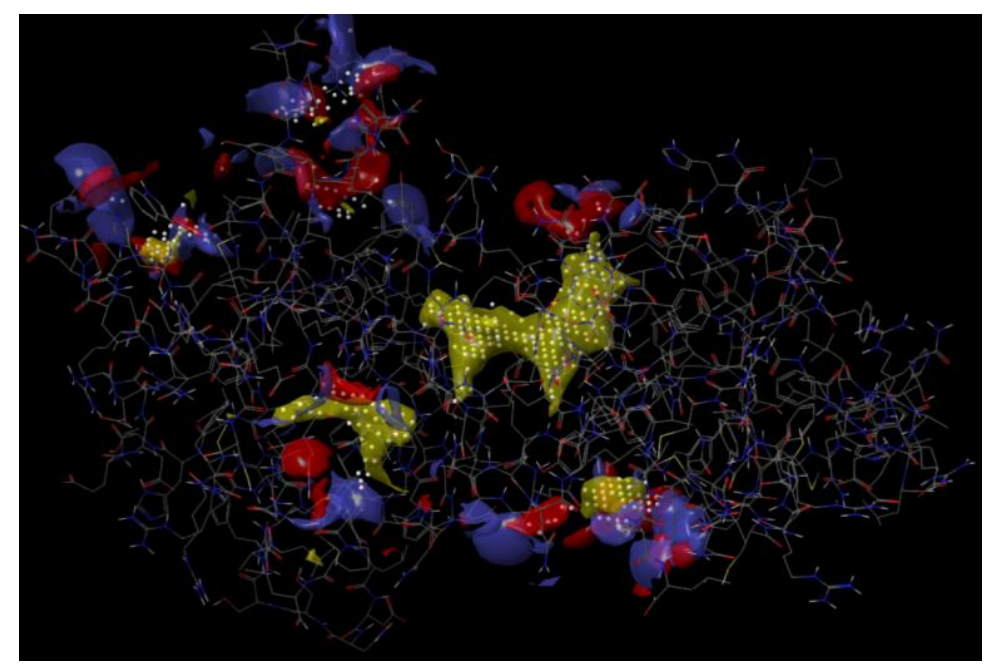

Figure 2. Detection of binding sites using Sitemap tool. 


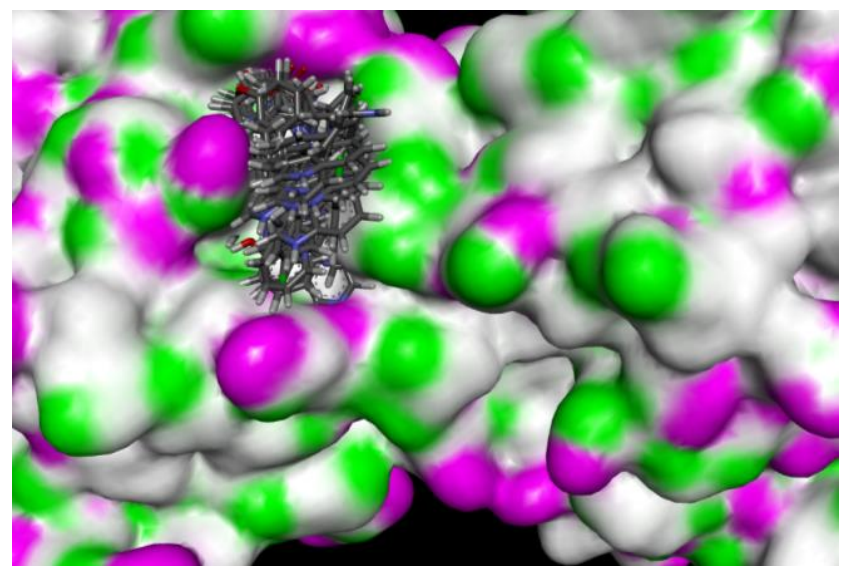

Figure 3. Docked molecules poses in the binding site of the AhR-ARNT complex.

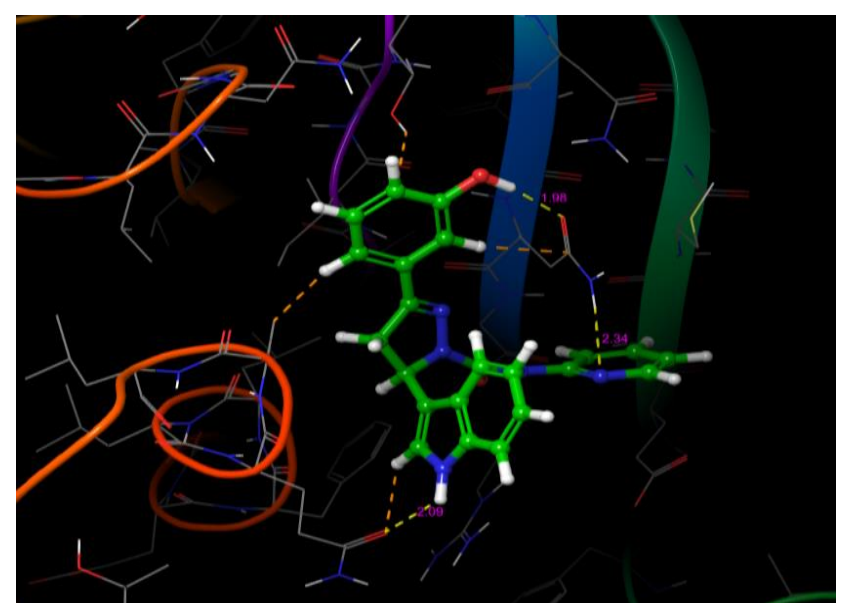

Figure 4. H-bonding interactions of compound after $4 \mathrm{~h}$ with the binding site residues.

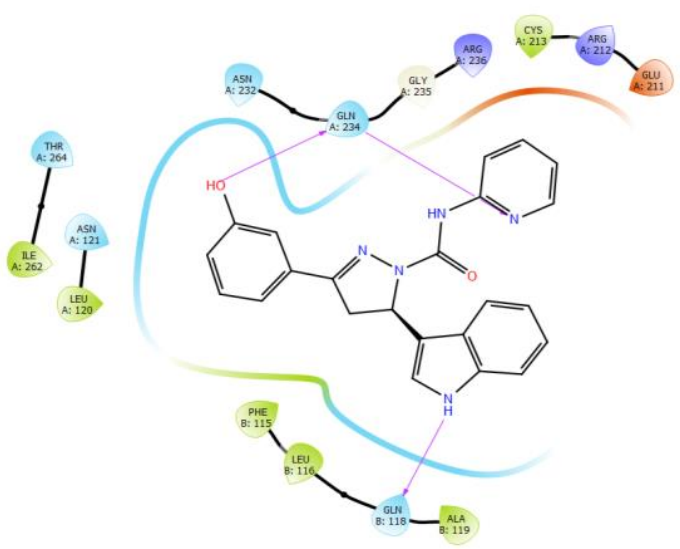

Figure 5. Two-dimensional representation of H-bonding interactions of compound after $4 \mathrm{~h}$ with the binding site residues. 


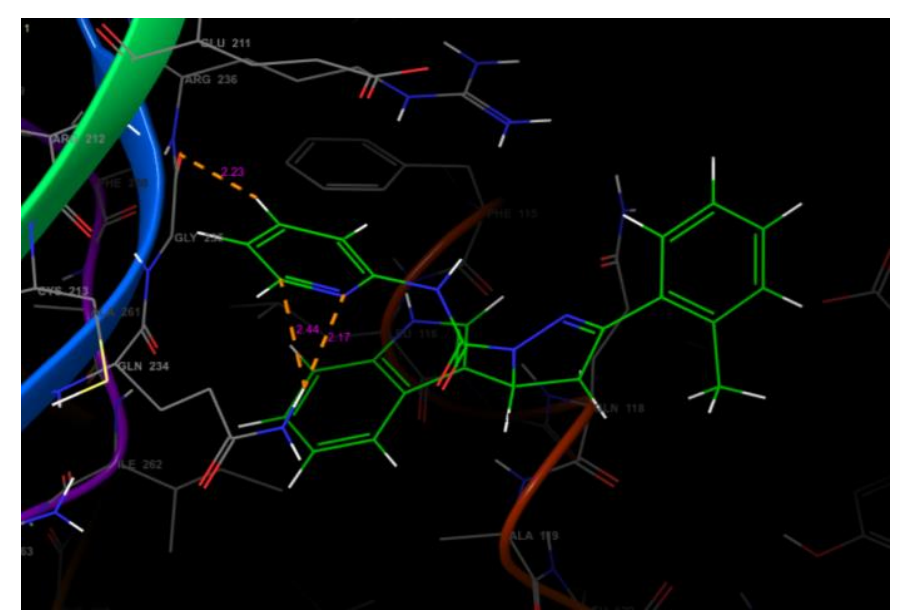

Figure 6. H-bonding interactions of compound after $4 \mathrm{~d}$ as visualized using pose viewer.

\subsection{Chemistry}

In the last decade, an extensive number of chemically synthesized pyrazolines have been reported; however, only a limited number of them were synthesized using the relatively straightforward one-pot reaction method. In this study, we describe the synthesis method with good yield and reduced reaction time for the synthesis of selected new pyrazolines by employing a one-pot synthesis method, in turn eliminating any tedious purification steps for the removal of intermediate chalcones. The synthesis scheme of the designed pyrazolines is outlined in Figure 1. In this study, the pyrazolines (3a-k) were synthesized in a single reaction flask using a one-pot synthesis method utilizing indole-3-aldehyde with different substituted acetophenone and hydrazine [46].

The desired pyrazoline compounds 4a-t were produced successfully by treating pyrazolines $(3 a-k)$ with phenyl chloroformate in the presence of triethylamine in tetrahydrofuran at $25-30{ }^{\circ} \mathrm{C}$. An equimolar quantity of triethylamine was used to neutralize the $\mathrm{HCl}$ fumes liberated during the reaction. No further isolation steps were necessary and the anhydride was yielded upon reaction with respective aryl/heteroaryl amines (4a-4t) [47].

The structures moieties of the newly synthesized compounds were confirmed with the help of their FT-IR, 1H NMR, mass spectroscopy, and elemental analysis (Supplementary Data). All the pyrazoline derivatives $(4 \mathrm{a}-\mathrm{t})$ displayed characteristic $\mathrm{N}-\mathrm{H}$ stretch $\left(3288-3438 \mathrm{~cm}^{-1}\right)$, C-H aromatic (3040-3134 $\left.\mathrm{cm}^{-1}\right), \mathrm{C}-\mathrm{H}$ aliphatic $\left(2816-2979 \mathrm{~cm}^{-1}\right), \mathrm{C}=\mathrm{O}\left(1662-1698 \mathrm{~cm}^{-1}\right)$, $\mathrm{C}=\mathrm{N}\left(1575-1630 \mathrm{~cm}^{-1}\right)$, and $\mathrm{C}=\mathrm{C}(1354-1607)$. The $1 \mathrm{H}$ NMR spectra of pyrazoline derivatives $(4 a-t)$ showed distinct and characteristic peaks. The protons were connected to the $C 4$ and $\mathrm{C} 5$ carbon atoms of the 2-pyrazoline as a (ABX) spin system [48] which occurred as two doubles and one doublet (d) to doublet (dd) signals between $\delta 3.29-3.39,3.72-3.92$, and 6.05-6.32 ppm for three protons to prove a pyrazoline ring. The $\mathrm{CH}$ proton of the pyrrole ring in the indole appeared as a singlet (s) signal between $\delta 7.91-8.11 \mathrm{ppm}$, and NH-indole proton between $\delta 10.41-10.76 \mathrm{ppm}$ also appeared as a singlet. Aryl protons exhibited its typical peaks between $\delta 6.49-8.03$ ppm as multiplets, and Aryl/Het Aryl-NH protons $\delta$ 9.99-10.15 ppm as a singlet. The three protons of Ar-CH3, one proton of Ar-OH, and three protons of Ar-OCH3 appeared at $\delta 2.22,9.75-9.97$, and 3.64-3.82 ppm, respectively, as a singlet peak.

\subsection{Anti-Proliferative Activity}

The synthesized pure pyrazoline molecules were subjected to in vitro cytotoxicity evaluations in four human cancer cell lines which utilized the MTT assay, including breast (MCF-7), liver (Hep-2), lung (A-549), and prostate (DU-145). The indole derivative isatin was used as a standard compound for comparison for the tested cell lines. The $\mathrm{IC}_{50}$ values were determined for all the tested compounds, and are presented in Table 3. It was found that the majority of the tested molecules showed substantial anti-proliferative activity 
against the tested cell lines. The molecules $4 \mathrm{~g}$, 4, and 4q, in particular, showed high anticancer potential across all the cell lines used in this study. The compounds possessing $\mathrm{o}, \mathrm{m}$, p-hydroxy phenyl group substitution on the pyrazoline ring showed promising anticancer activities in all tested cell lines; however, this may also be attributed to the aminopyridine. As evident from the docking simulations, both aryl and pyridine rings play an important role in the H-bonding formation with the AhR-ARNT complex protein.

Table 3. Anticancer potential of compounds 4(a-t) in select experimental human cancer cell lines.

\begin{tabular}{|c|c|c|c|c|c|c|}
\hline \multirow{2}{*}{ Compound } & \multirow{2}{*}{$\mathbf{R}$} & \multirow{2}{*}{ R1 } & \multicolumn{4}{|c|}{$\mathrm{IC}_{50}(\mu \mathrm{M})$} \\
\hline & & & A-549 & MCF-7 & Hep G-2 & DU-145 \\
\hline $4 a$ & $\mathrm{H}$ & Pyridin-2-yl & $4.75 \pm 0.21$ & $54.32 \pm 0.52$ & $22.29 \pm 0.30$ & $19.53 \pm 0.11$ \\
\hline $4 b$ & $2-\mathrm{Cl}$ & Pyridin-2-yl & $5.79 \pm 0.13$ & $59.01 \pm 0.46$ & $21.61 \pm 0.25$ & $19.68 \pm 0.15$ \\
\hline $4 c$ & $3-\mathrm{Cl}$ & Pyridin-2-yl & $5.32 \pm 0.17$ & $60.64 \pm 0.27$ & $24.55 \pm 0.26$ & $16.54 \pm 0.08$ \\
\hline $4 d$ & $3-\mathrm{CH} 3$ & Pyridin-2-yl & $7.89 \pm 0.26$ & $56.58 \pm 0.36$ & $26.32 \pm 0.14$ & $16.02 \pm 0.26$ \\
\hline $4 \mathrm{e}$ & 3-OCH3 & Pyridin-2-yl & $5.78 \pm 0.15$ & $54.93 \pm 0.31$ & $32.57 \pm 0.25$ & $15.67 \pm 0.21$ \\
\hline $4 \mathrm{f}$ & 4-OCH3 & Pyridin-2-yl & $6.83 \pm 0.16$ & $58.76 \pm 0.34$ & $34.95 \pm 0.13$ & $16.84 \pm 0.18$ \\
\hline $4 g$ & 2-OH & Pyridin-2-yl & $2.32 \pm 0.11$ & $43.59 \pm 0.38$ & $24.53 \pm 0.17$ & $14.53 \pm 0.16$ \\
\hline $4 \mathrm{~h}$ & $3-\mathrm{OH}$ & Pyridin-2-yl & $4.56 \pm 0.14$ & $47.45 \pm 0.28$ & $26.30 \pm 0.14$ & $12.36 \pm 0.15$ \\
\hline $4 \mathrm{i}$ & $4-\mathrm{OH}$ & Pyridin-2-yl & $5.74 \pm 0.012$ & $52.18 \pm 0.12$ & $30.22 \pm 0.19$ & $13.50 \pm 0.14$ \\
\hline $4 \mathrm{j}$ & 2-NO2 & Pyridin-2-yl & $7.77 \pm 0.26$ & $64.78 \pm 0.46$ & $35.50 \pm 0.12$ & $19.63 \pm 0.15$ \\
\hline $4 \mathrm{k}$ & 3-NO2 & Pyridin-2-yl & $8.81 \pm 0.13$ & $75.36 \pm 0.34$ & $33.77 \pm 0.15$ & $16.76 \pm 0.17$ \\
\hline 41 & $2-\mathrm{Cl}$ & Pyridin-3-yl & $6.46 \pm 0.22$ & $45.30 \pm 0.26$ & $27.74 \pm 0.26$ & $19.75 \pm 0.12$ \\
\hline $4 \mathrm{~m}$ & $2-\mathrm{OH}$ & Pyridin-3-yl & $3.92 \pm 0.24$ & $57.18 \pm 0.31$ & $21.60 \pm 0.29$ & $10.15 \pm 0.13$ \\
\hline $4 n$ & $3-\mathrm{OH}$ & Pyridin-3-yl & $5.45 \pm 0.14$ & $55.74 \pm 0.42$ & $29.52 \pm 0.21$ & $13.99 \pm 0.19$ \\
\hline 40 & $4-\mathrm{Cl}$ & Pyridin-4-yl & $6.78 \pm 0.16$ & $54.84 \pm 0.27$ & $30.53 \pm 0.19$ & $14.65 \pm 0.21$ \\
\hline $4 p$ & 4-OCH3 & Pyridin-4-yl & $5.74 \pm 0.15$ & $54.23 \pm 0.29$ & $26.25 \pm 0.24$ & $15.52 \pm 0.15$ \\
\hline $4 q$ & $2-\mathrm{OH}$ & Pyridin-4-yl & $2.86 \pm 0.12$ & $46.13 \pm 0.34$ & $21.12 \pm 0.16$ & $9.92 \pm 0.13$ \\
\hline $4 r$ & $3-\mathrm{OH}$ & Pyridin-4-yl & $4.50 \pm 0.18$ & $56.50 \pm 0.37$ & $25.87 \pm 0.15$ & $12.16 \pm 0.17$ \\
\hline $4 \mathrm{~s}$ & $2-\mathrm{OH}$ & Phenyl & $3.02 \pm 0.14$ & $48.67 \pm 0.34$ & $22.28 \pm 0.17$ & $10.47 \pm 0.16$ \\
\hline $4 \mathrm{t}$ & $4-\mathrm{OH}$ & Phenyl & $5.26 \pm 0.19$ & $66.53 \pm 0.31$ & $25.94 \pm 0.12$ & $12.19 \pm 0.22$ \\
\hline Isatin & & & $4.96 \pm 0.21$ & $32.61 \pm 0.25$ & $28.29 \pm 0.14$ & $19.64 \pm 0.12$ \\
\hline
\end{tabular}

The compounds containing hydroxy phenyl substitutions, such as $4 \mathrm{~g}, 4 \mathrm{q}$, and $4 \mathrm{~s}$, are relatively more potent among all the other tested compounds with $\mathrm{IC}_{50}$ values of $2.32 \pm 0.11$, $2.86 \pm 0.12$, and $3.02 \pm 0.14 \mu \mathrm{M}$, respectively, when tested against the lung cancer cell line (A-549). Similarly, the compounds $4 \mathrm{~g}$, $4 \mathrm{~h}$, and $4 \mathrm{q}$ showed good anti-proliferative activity against the breast (MCF-7) cancer cell line with $\mathrm{IC}_{50}$ values of $43.59 \pm 0.38,47.45 \pm 0.28$, and $46.13 \pm 0.34 \mu \mathrm{M}$, respectively. However, in case of the liver cancer cell line (Hep-2), the hydroxy phenyl substituted compounds showed $\mathrm{IC}_{50}$ values ranging between $21.12 \pm 0.16$ to $30.22 \pm 0.19 \mu \mathrm{M}$, while other compounds containing unsubstituted phenyl (4a), and 2-Chloro phenyl substituted (4b) compounds also showed better anti-proliferative activity with $\mathrm{IC}_{50}$ values of $22.29 \pm 0.30,21.61 \pm 0.25 \mu \mathrm{M}$, respectively. In the prostate cancer cell line (DU-145), the compounds with m-hydroxy phenyl substituted compounds (4h, $4 \mathrm{n}$, $4 \mathrm{r}$ ) with the irrespective pyridine group for carboxamide substitution showed promising inhibitory activity. In all the cases, some of the newly synthesized compounds showed promising activities than the standard compounds in the tested cell lines.

In most of the cases, hydroxy substitution at the 2-, 3- and 4-position of the phenyl ring led to substantial improvement in the therapeutic potency. Incorporation of a carboxamide group with various aminopyridines also resulted in a considerable improvement in anti-proliferative activity in most of the cell lines tested. Some of molecules synthesized in this study demonstrated notable therapeutic efficacy exclusively in the lung and prostate cancer cell line with $\mathrm{IC}_{50}$ values up to $2.32 \pm 0.11$ and $9.92 \pm 0.13 \mu \mathrm{M}$, respectively. This enhanced anti-tumorigenic activity may be attributed to the inclusion of the indole moiety to the pyrazoline nucleus which may lead to possible interaction binding with the AhR-ARNT complex for enhanced chemotherapeutic effects. However, further in-depth 
investigations with suitable structural modifications in both the pyrazoline and indole moieties are required to gain a better understanding into the mechanism of action of indolyl dihydropyrazole derivatives.

\section{Conclusions}

This study describes the synthesis of a novel series of molecules designed in purview of the therapeutic properties of indole scaffold, incorporating a pyrazoline nucleus with the assumption of a possible interaction with an aryl hydrocarbon receptor for enhanced chemotherapeutic effects. The designed molecules were subjected to molecular docking analysis, and a few molecules were selected for synthesis and in vitro cytotoxicity testing using the MTT assay in different human cancer cell lines. Most of the synthesized compounds interacted with the AhR-ARNT complex by H-bonding interactions. The cytotoxicity assay of the hydroxy-phenyl-substituted compounds yielded potential antitumorigenic effects. The results of this study indicate that these scaffolds could be utilized as potential anticancer agents, and that the structural modification in both indole and pyrazoline nucleus play a major role in enhancing the anticancer efficiency.

Supplementary Materials: Supplementary Data are available online.

Author Contributions: Conceptualization, K.N.V. and A.H.A.; Data curation, K.N.V., M.H. and A.H.A.; Formal analysis, M.H., B.E.A. and A.H.A.; Funding acquisition, K.N.V., M.H., B.E.A. and A.H.A.; Investigation, K.N.V., M.H., B.E.A. and A.H.A.; Methodology, K.N.V., M.H., B.E.A. and A.H.A.; Project administration, B.E.A.; Resources, K.N.V. and A.H.A.; Software, K.N.V.; Supervision, M.H. and B.E.A.; Validation, K.N.V., M.H., B.E.A. and A.H.A.; Writing-original draft, K.N.V., M.H., B.E.A. and A.H.A.; Writing-review \& editing, K.N.V. and A.H.A. All authors have read and agreed to the published version of the manuscript.

Funding: This research was funded by Deanship of Scientific Research at King Faisal University, for the financial support under Nasher track (Grant No. 206021).

Conflicts of Interest: The authors declare no conflict of interest.

Sample Availability: Samples of the compounds are available from the authors.

\section{References}

1. Perdew, G.H. Association of the Ah receptor with the 90-kDa heat shock protein. J. Biol. Chem. 1988, 263, 13802-13805. [CrossRef]

2. Meyer, B.K.; Pray-Grant, M.G.; Vanden Heuvel, J.P.; Perdew, G.H. Hepatitis B Virus X-Associated Protein 2 Is a Subunit of the Unliganded Aryl Hydrocarbon Receptor Core Complex and Exhibits Transcriptional Enhancer Activity. Mol. Cell. Biol. 1998, 18, 978-988. [CrossRef]

3. Kazlauskas, A.; Poellinger, L.; Pongratz, I. Evidence that the co-chaperone p23 regulates ligand responsiveness of the dioxin (aryl hydrocarbon) receptor. J. Biol. Chem. 1999, 274, 13519-13524. [CrossRef]

4. Petrulis, J.R.; Perdew, G.H. The role of chaperone proteins in the aryl hydrocarbon receptor core complex. Chem. Biol. Interact. 2002, 141, 25-40. [CrossRef]

5. Denison, M.S.; Nagy, S.R. Activation of the Aryl Hydrocarbon Receptor by Structurally Diverse Exogenous and Endogenous Chemicals. Annu. Rev. Pharmacol. Toxicol. 2003, 43, 309-334. [CrossRef] [PubMed]

6. Reyes, H.; Reisz-Porszasz, S.; Hankinson, O. Identification of the Ah receptor nuclear translocator protein (Arnt) as a component of the DNA binding form of the Ah receptor. Science 1992, 256, 1193-1195. [CrossRef] [PubMed]

7. Lusska, A.; Shen, E.; Whitlock, J.P. Protein-DNA interactions at a dioxin-responsive enhancer. Analysis of six bona fide DNAbinding sites for the liganded Ah receptor. J. Biol. Chem. 1993, 268, 6575-6580. [CrossRef]

8. Denison, M.S.; Soshilov, A.A.; He, G.; Degroot, D.E.; Zhao, B. Exactly the same but different: Promiscuity and diversity in the molecular mechanisms of action of the aryl hydrocarbon (dioxin) receptor. Toxicol. Sci. 2011, 124, 1-22. [CrossRef]

9. Soshilov, A.; Denison, M.S. Ligand displaces heat shock protein 90 from overlapping binding sites within the aryl hydrocarbon receptor ligandbinding domain. J. Biol. Chem. 2011, 286, 35275-35282. [CrossRef]

10. Carreira, V.S.; Fan, Y.; Kurita, H.; Wang, Q.; Ko, C.I.; Naticchioni, M.; Jiang, M.; Koch, S.; Zhang, X.; Biesiada, J.; et al. Disruption of ah receptor signaling during mouse development leads to abnormal cardiac structure and function in the adult. PLoS ONE 2015, 10, e0142440. [CrossRef]

11. Dever, D.P.; Adham, Z.O.; Thompson, B.; Genestine, M.; Cherry, J.; Olschowka, J.A.; DiCicco-Bloom, E.; Opanashuk, L.A. Aryl hydrocarbon receptor deletion in cerebellar granule neuron precursors impairs neurogenesis. Dev. Neurobiol. 2016, 76, 533-550. [CrossRef] [PubMed] 
12. Yamada, T.; Horimoto, H.; Kameyama, T.; Hayakawa, S.; Yamato, H.; Dazai, M.; Takada, A.; Kida, H.; Bott, D.; Zhou, A.C.; et al. Constitutive aryl hydrocarbon receptor signaling constrains type I interferon-mediated antiviral innate defense. Nat. Immunol. 2016, 17, 687-694. [CrossRef] [PubMed]

13. Yin, J.; Sheng, B.; Qiu, Y.; Yang, K.; Xiao, W.; Yang, H. Role of AhR in positive regulation of cell proliferation and survival. Cell Prolif. 2016, 49, 554-560. [CrossRef]

14. Thatcher, T.H.; Williams, M.A.; Pollock, S.J.; McCarthy, C.E.; Lacy, S.H.; Phipps, R.P.; Sime, P.J. Endogenous ligands of the aryl hydrocarbon receptor regulate lung dendritic cell function. Immunology 2016, 147, 41-54. [CrossRef]

15. Murray, I.A.; Patterson, A.D.; Perdew, G.H. Aryl hydrocarbon receptor ligands in cancer: Friend and foe. Nat. Rev. Cancer 2014, 14, 801-814. [CrossRef]

16. Hubbard, T.D.; Murray, I.A.; Perdew, G.H. Special Section on Drug Metabolism and the Microbiome-Minireview Indole and Tryptophan Metabolism: Endogenous and Dietary Routes to Ah Receptor Activation. Drug Metab. Dispos. 2015, 43, 1522-1535. [CrossRef] [PubMed]

17. Schiering, C.; Wincent, E.; Metidji, A.; Iseppon, A.; Li, Y.; Potocnik, A.J.; Omenetti, S.; Henderson, C.J.; Wolf, C.R.; Nebert, D.W.; et al. Feedback control of AHR signalling regulates intestinal immunity. Nature 2017, 542, 242-245. [CrossRef]

18. Schroeder, J.C.; DiNatale, B.C.; Murray, I.A.; Flaveny, C.A.; Liu, Q.; Laurenzana, E.M.; Lin, J.M.; Strom, S.C.; Omiecinski, C.J.; Amin, S.; et al. The uremic toxin 3-indoxyl sulfate is a potent endogenous agonist for the human aryl hydrocarbon receptor. Biochemistry 2010, 49, 393-400. [CrossRef]

19. Shimizu, H.; Bolati, D.; Higashiyama, Y.; Nishijima, F.; Shimizu, K.; Niwa, T. Indoxyl sulfate upregulates renal expression of MCP-1 via production of ROS and activation of NF-KB, p53, ERK, and JNK in proximal tubular cells. Life Sci. 2012, 90, 525-530. [CrossRef]

20. Yisireyili, M.; Takeshita, K.; Saito, S.; Murohara, T.; Niwa, T. Indole-3-propionic acid suppresses indoxyl sulfate-induced expression of fibrotic and inflammatory genes in proximal tubular cells. Nagoya J. Med. Sci. 2017, 79, 477-486. [CrossRef]

21. Quintana, F.J.; Basso, A.S.; Iglesias, A.H.; Korn, T.; Farez, M.F.; Bettelli, E.; Caccamo, M.; Oukka, M.; Weiner, H.L. Control of Treg and TH17 cell differentiation by the aryl hydrocarbon receptor. Nature 2008, 453, 65-71. [CrossRef] [PubMed]

22. Aoki, R.; Aoki-Yoshida, A.; Suzuki, C.; Takayama, Y. Indole-3-Pyruvic Acid, an Aryl Hydrocarbon Receptor Activator, Suppresses Experimental Colitis in Mice. J. Immunol. 2018, 201, 3683-3693. [CrossRef]

23. Furumatsu, K.; Nishiumi, S.; Kawano, Y.; Ooi, M.; Yoshie, T.; Shiomi, Y.; Kutsumi, H.; Ashida, H.; Fujii-Kuriyama, Y.; Azuma, T.; et al. A role of the aryl hydrocarbon receptor in attenuation of colitis. Dig. Dis. Sci. 2011, 56, 2532-2544. [CrossRef]

24. Wang, H.; Du, Z.; Zhang, C.; Tang, Z.; He, Y.; Zhang, Q.; Zhao, J.; Zheng, X. Biological evaluation and 3D-QSAR studies of curcumin analogues as aldehyde dehydrogenase 1 inhibitors. Int. J. Mol. Sci. 2014, 15, 8795-8807. [CrossRef] [PubMed]

25. Ma, Y.; Wang, Q.; Yu, K.; Fan, X.; Xiao, W.; Cai, Y.; Xu, P.; Yu, M.; Yang, H. 6-Formylindolo(3,2-b)carbazole induced aryl hydrocarbon receptor activation prevents intestinal barrier dysfunction through regulation of claudin-2 expression. Chem. Biol. Interact. 2018, 288, 83-90. [CrossRef] [PubMed]

26. Rannug, A.; Rannug, U. The tryptophan derivative 6-formylindolo[3,2- $b]$ carbazole, FICZ, a dynamic mediator of endogenous aryl hydrocarbon receptor signaling, balances cell growth and differentiation. Crit. Rev. Toxicol. 2018, 48, 555-574. [CrossRef]

27. Rzemieniec, J.; Wnuk, A.; Lasoń, W.; Bilecki, W.; Kajta, M. The neuroprotective action of 3,3'-diindolylmethane against ischemia involves an inhibition of apoptosis and autophagy that depends on HDAC and AhR/CYP1A1 but not ER $\alpha / C Y P 19 A 1$ signaling. Apoptosis 2019, 24, 435-452. [CrossRef] [PubMed]

28. Marconett, C.N.; Sundar, S.N.; Poindexter, K.M.; Stueve, T.R.; Bjeldanes, L.F.; Firestone, G.L. Indole-3-carbinol triggers aryl hydrocarbon receptor-dependent estrogen receptor (ER) $\alpha$ protein degradation in breast cancer cells disrupting an ER $\alpha$ GATA3 transcriptional cross-regulatory loop. Mol. Biol. Cell 2010, 21, 1166-1177. [CrossRef]

29. Zhu, G.; Conner, S.E.; Zhou, X.; Shih, C.; Li, T.; Anderson, B.D.; Brooks, H.B.; Morris Campbell, R.; Considine, E.; Dempsey, J.A.; et al. Synthesis, structure-activity relationship, and biological studies of indolocarbazoles as potent cyclin D1-CDK4 inhibitors. J. Med. Chem. 2003, 46, 2027-2030. [CrossRef]

30. Frideling, A.; Faure, R.; Galy, J.P.; Kenz, A.; Alkorta, I.; Elguero, J. Tetrahydroacridin-9-ones, 9-chlorotetrahydroacridines, 9-amino-tetrahydroacridines and 9-(pyrazol-1-yl)-tetrahydroacridines derived from chiral cyclanones. Eur. J. Med. Chem. 2004, 39, 37-48. [CrossRef]

31. David, T.I.; Adelakun, N.S.; Omotuyi, O.I.; Metibemu, D.S.; Ekun, O.E.; Eniafe, G.O.; Inyang, O.K.; Adewumi, B.; Enejoh, O.A.; Owolabi, R.T.; et al. Molecular docking analysis of phyto-constituents from Cannabis sativa with pfDHFR. Bioinformation 2018, 14, 574-579. [CrossRef]

32. Kellici, T.F.; Ntountaniotis, D.; Liapakis, G.; Tzakos, A.G.; Mavromoustakos, T. The dynamic properties of angiotensin II type 1 receptor inverse agonists in solution and in the receptor site. Arab. J. Chem. 2019, 12, 5062-5078. [CrossRef]

33. Wu, D.; Potluri, N.; Kim, Y.; Rastinejad, F. Structure and Dimerization Properties of the Aryl Hydrocarbon Receptor PAS-A Domain. Mol. Cell. Biol. 2013, 33, 4346-4356. [CrossRef] [PubMed]

34. Friesner, R.A.; Banks, J.L.; Murphy, R.B.; Halgren, T.A.; Klicic, J.J.; Mainz, D.T.; Repasky, M.P.; Knoll, E.H.; Shelley, M.; Perry, J.K.; et al. Glide: A New Approach for Rapid, Accurate Docking and Scoring. 1. Method and Assessment of Docking Accuracy. J. Med. Chem. 2004, 47, 1739-1749. [CrossRef] 
35. Friesner, R.A.; Murphy, R.B.; Repasky, M.P.; Frye, L.L.; Greenwood, J.R.; Halgren, T.A.; Sanschagrin, P.C.; Mainz, D.T. Extra precision glide: Docking and scoring incorporating a model of hydrophobic enclosure for protein-ligand complexes. J. Med. Chem. 2006, 49, 6177-6196. [CrossRef]

36. Bowkett, D.; Talon, R.; Tallant, C.; Schofield, C.; von Delft, F.; Knapp, S.; Bruton, G.; Brennan, P.E. Identifying Small-Molecule Binding Sites for Epigenetic Proteins at Domain-Domain Interfaces. Chem. Med. Chem. 2018, 13, 1051-1057. [CrossRef]

37. Halgren, T. New method for fast and accurate binding-site identification and analysis. Chem. Biol. Drug Des. 2007, 69, 146-148. [CrossRef] [PubMed]

38. Halgren, T.A. Identifying and characterizing binding sites and assessing druggability. J. Chem. Inf. Model. 2009, 49, 377-389. [CrossRef]

39. Palmioli, A.; Ciaramelli, C.; Tisi, R.; Spinelli, M.; De Sanctis, G.; Sacco, E.; Airoldi, C. Natural Compounds in Cancer Prevention: Effects of Coffee Extracts and Their Main Polyphenolic Component, 5-O-Caffeoylquinic Acid, on Oncogenic Ras Proteins. Chem. Asian J. 2017, 12, 2457-2466. [CrossRef] [PubMed]

40. Sherman, W.; Beard, H.S.; Farid, R. Use of an Induced Fit Receptor Structure in Virtual Screening. Chem. Biol. Drug Des. 2006, 67, 83-84. [CrossRef]

41. Mandal, R.S.; Ta, A.; Das, S. In silico designing and experimental validation of a potential small molecule inhibitor against vibrio cholerae AphB. In Proceedings of the 5th ACM Conference on Bioinformatics, Computational Biology, and Health InformaticsBCB '14, Newport Beach, CA, USA, 20-23 September 2014; Association for Computing Machinery (ACM): New York, NY, USA; p. 585. [CrossRef]

42. Taj, T.; Kamble, R.R.; Gireesh, T.M.; Hunnur, R.K.; Margankop, S.B. One-pot synthesis of pyrazoline derivatised carbazoles as antitubercular, anticancer agents, their DNA cleavage and antioxidant activities. Eur. J. Med. Chem. 2011, 46, 4366-4373. [CrossRef]

43. Lokhande, P.D.; Sakate, S.S. Regioselective one-pot synthesis of 3,5-diarylpyrazoles. Indian J Chem. 2005, 44, 2338-2342. [CrossRef]

44. Kamal, A.; Srikanth, Y.V.V.; Khan, M.N.A.; Shaik, T.B.; Ashraf, M. Synthesis of 3,3-diindolyl oxyindoles efficiently catalysed by $\mathrm{FeCl} 3$ and their in vitro evaluation for anticancer activity. Bioorg. Med. Chem. Lett. 2010, 20, 5229-5231. [CrossRef] [PubMed]

45. Lakshmi, N.V.; Thirumurugan, P.; Noorulla, K.M.; Perumal, P.T. InCl3 mediated one-pot multicomponent synthesis, anti-microbial, antioxidant and anticancer evaluation of 3-pyranyl indole derivatives. Bioorg. Med. Chem. Lett. 2010, 20, 5054-5061. [CrossRef]

46. Hawaiz, F.E.; Hussein, A.J.; Samad, M.K. One-pot three-component synthesis of some new azo-pyrazoline derivatives. Eur. J. Chem. 2014, 5, 233-236. [CrossRef]

47. Kulandaivelu, U.; Padmini, V.G.; Suneetha, K.; Shireesha, B.; Vidyasagar, J.V.; Rao, T.R.; KN, J.; Basu, A.; Jayaprakash, V. Synthesis, Antimicrobial and Anticancer Activity of New Thiosemicarbazone Derivatives. Archiv der Pharmazie. 2011, 344, 84-90. [CrossRef] [PubMed]

48. Karuppasamy, M.; Mahapatra, M.; Yabanoglu, S.; Ucar, G.; Sinha, B.N.; Basu, A.; Mishra, N.; Sharon, A.; Kulandaivelu, U.; Jayaprakash, V. Development of selective and reversible pyrazoline based MAO-A inhibitors: Synthesis, biological evaluation and docking studies. Bioorg. Med. Chem. 2010, 18, 1875-1881. [CrossRef] [PubMed] 